\title{
Intratubular Non-Seminoma
}

National Cancer Institute

\section{Source}

National Cancer Institute. Intratubular Non-Seminoma. NCI Thesaurus. Code C7325.

Intratubular germ cell neoplasia characterized by the presence of almost exclusively pure embryonal carcinoma cells. 